\title{
The potential of Nephrolepis biserrata fern as ground cover vegetation in oil palm plantation
}

\author{
HALUS SATRIAWAN`, ZAHRUL FUADY, ERNAWITA \\ Department of Agrotechnology, Faculty of Agriculture, Universitas Almuslim. Jl. Almuslim No. 37, Matang Glumpang Dua, Peusangan, Bireuen 24261, \\ Aceh, Indonesia. Tel./fax.: +62-644-442166, •email: satriawan_80@yahoo.co.id
}

Manuscript received: 7 September 2021. Revision accepted: 16 October 2021.

\begin{abstract}
Satriawan H, Fuady Z, Ernawita. 2021. The potential of Nephrolepis biserrata fern as ground cover vegetation in oil palm plantation. Biodiversitas 22: 4808-4817. Nuisance plants or weeds are commonly found in agricultural landscapes including in oil palm plantations. Despite being considered as weeds, several of them have the potential to be used as ground cover vegetation including Nephrolepis biserrata (Sw). Schott. This fern species exhibits beneficial characteristics as a ground cover plant, especially in terms of the contribution of organic matter and soil moisture through the prevention of evapotranspiration. The objective of this research is to explore the potential of N.biserrata as ground cover vegetation in oil palm plantations based on the assessment of its ecological characteristics regarding the growth and decomposition rate, tolerance to shade, organic contents and carbon accumulation. The splitplot experimental design was used with the age of oil palm plants was used as the main plot while in the sub-plots, the spacing of $N$. biserrata was used at three varying distances $10 \times 10 \mathrm{~cm}, 20 \times 20 \mathrm{~cm}$, and $30 \times 30 \mathrm{~cm}$, each treatment had three replicates. Nine parameters observed were the percentage of growth, the percentage of ground cover, plant height, fronds number per plant, leaves number per plant, Leaf Area Index, dry weight (g), nutrient content in plant tissue, and potential carbon stock. Results showed that $N$. biserrata showed rapid growth in covering the ground surface (8-12 weeks after planting), had rapid decomposition rate (30-60 days), tolerant to shading which was characterized by the highest percentage of growth up to $81.16 \%$ and covering the area up to $95.9 \%$, accumulated organic contents of $\mathrm{N}(1.23-1.53 \%), \mathrm{P}(0.18-0.22 \%)$, and $\mathrm{K}(1.4-1.67 \%)$, respectively. In addition, total dry weight biomass obtained was 27.1 ton/ha, accumulated carbon in a plant of 0.9 tons $\mathrm{C} /$ ha/year, and amount of soil carbon stock 76.4-97.4 tonnes/ha/year. The results of this study suggest that Nephrolepis biserrata is a potential plant to be utilized as a ground cover plant in oil palm plantations.
\end{abstract}

Keywords: Biomass, carbon plant, cover crops, Nephrolepis biserrata, soil carbon stock

\section{INTRODUCTION}

The rapid growth of the human population and consumption has triggered the expansion of agricultural lands globally (Bonhommeau et al. 2013; Godfray et al. 2010; Tilman et al. 2001). Tropical regions, which harbor a great level of biodiversity and forest covers, show the most rapid change of land uses along with its socioeconomic conditions (Laurance et al. 2014). Among agricultural crops, oil palms (Elaeis guineensis) of Arecaceae are widely planted across large areas in Southeast Asia to produce palm oil. Between 2000-2010, it is recorded that the total oil palm plantations area in Southeast Asia increased by $87 \%$ in just ten years (Wilcove et al. 2013).

Indonesia and Malaysia have the largest share of global palm oil producers, contributing to over $80 \%$ of the total world's supply (over 46 million tonnes per year) (FAO), 2017). In Indonesia, oil palm is the largest export commodity compared to other estate crops with a total value of over US\$ 14.7 billion (Statista 2020). In 2016, around 35.3 million tonnes of crude palm oil (CPO) were produced (Ditjenbun, 2017). The total plantation area in the country increased from 9 million ha in 2010 (Putra et al. 2012) to more than 15 million hectares in 2021 (Rodríguez et al. 2021) with the rate of land conversions was 450,000 ha/year between 1995 and 2015 (Austin et al. 2017). At a provincial level of Aceh, oil palm plantation areas are close to 400 thousand ha with a composition of $50.41 \%$ is owned by the company while $49.59 \%$ is smallholder plantation (BKPM, 2017) with a total production of crude palm oil (CPO) reached 0.73 million tonnes (Ditjenbun, 2017).

Besides the land conversion problem, the expansion of oil palm also causes the widespread of weeds with some of them being invasive alien species. Studies have reported up to 60 species of plants categorized as weeds in oil palm plantations such as Asystasia gangetica, Clidemia hirta, Dyrnaria cordata, Imperata cylindrica, Trema cannabina, and Oxalis barrelieri (Ali et al. 2021; Norlindawati et al. 2019). While considered as a nuisance, weeds in oil palm plantations can serve as cover crops that provide various ecological functions, including reducing the speed of runoff water, preventing soil erosion and nitrogen leaching, improving soil organic matter, prohibiting the presence of other weeds through competition and reducing soilborne pathogens (Kanders et al. 2017; Larkin et al. 2015; Liu et al. 2021; Wen et al. 2017). However, several conditions have to be met so that weeds can be used as cover crops, i.e., simple propagation, rapid growth and covering ability, abundant leaves and branches, ability to grow in low fertility soil, non-competitive with main crops in terms of nutrient absorbance (Department of Agriculture, 2013), high biomass production (Satriawan and Fuady 2014), high nitrogen upturn, nutrient balance ability, and soil structure improvement ability (Kruidhof et al. 2009). 
One of the most common types of weeds reported in oil palm plantations in Indonesia is fern Nephrolepis biserrata. Satriawan and Fuady (2019) stated that N. biserrata is generally found under oil palm stands with the age of more than five years old. $N$. biserrata is useful as a ground cover plant since it grows slowly in the form of shrubs and its presence does not cause much harm or disturbance to the oil palm planted so that $N$. biserrata tends to be maintained in oil palm plantations. Its serves as a cover plant that can improve water and soil capacity. The rhizomes of $N$. biserrata are able to enhance the space of soil pores particularly at the subsoil level which influences groundwater upsurge. In such conditions, the presence of $N$. biserrata can mitigate water shortages during the dry season. With good administration, $N$. biserrata has a great potential to be utilized as a ground cover crop in welldeveloped oil palm plantations. It has preferable characteristics such as being able to grow well in poor soil conditions (Samedani et al. 2013) and in shaded conditions (Adeleye et al. 2017). Thus, the study aimed to examine the potential of $N$. biserrata as a cover crop in oil palm plantation based on the assessment of its ecological characteristics regarding the growth and decomposition rate, tolerance to shade, organic contents and carbon accumulation.

\section{MATERIALS AND METHODS}

\section{Study area and experimental design}

The experiment was conducted at oil palm plantations located in South Peusangan Sub-district, Bireuen District, Aceh Province, Indonesia. Oil palms were aged eight, seven, and six years old (planted in 2012, 2013 and 2014, consecutively). A split-plot was used as an experimental design in which the main plots were the age of oil palm plants $(8,7$, and 6 years old), while the spacing of $N$. biserrata was determined as a subplot $(10 \times 10 \mathrm{~cm}, 20 \times 20$ $\mathrm{cm}$, and $30 \times 30 \mathrm{~cm})$. Each treatment was conducted in triplicates.

The experimental land was loosened using a hoe on a $20 \mathrm{~cm}$ high tillage layer. Furthermore, experimental plots measuring $2.5 \times 2 \mathrm{~m}$ were made, and stem cuttings of $N$. biserrata (15 cm or two segments) were planted between rows of oil palm plants according to determined spacing treatment.

\section{Parameters}

Parameters observed were growth parameters of $N$. Biserrata, biomass and soil carbon parameters. The growth parameters of $N$. biserrata consisted of five measurements. First was the percentage of growth observed at 4, 8, and 12 weeks after planting (WAP). The second was the percentage of land covered by $N$. biserrata at 4,8 , and 12 WAP. This parameter was measured using a wire measuring $1 \mathrm{~m} \times 1 \mathrm{~m}$ in which there were small meshes measuring $10 \mathrm{~cm} \times 10 \mathrm{~cm}$. The following formula was used to measure land cover:

$\% \mathrm{LC}=\mathrm{A} / \mathrm{B} \times 100 \%$
Where: LC: land cover; A: number of meshes covered by $N$. biserrata; B: total meshes

Third was plant height $(\mathrm{cm})$ at age 2-20 WAP. And fourth was the number of fronds per plant at age 8-20 WAP. Fifth was total Leaf Area per plant $\left(\mathrm{cm}^{2}\right)$ using the gravimetric method as follows: leaf pattern (leaf replica) was drawn on plain paper and leaf replicas were weighed using an analytical balance; then a piece of paper measuring $10 \mathrm{~cm}$ x $10 \mathrm{~cm}$ was made and weighed. Leaf Area was calculated using the following formula:

Leaf Area $=($ weight of leaf replica/weight of paper $10 \mathrm{x}$ $10 \mathrm{~cm}) \times 100 \mathrm{~cm}^{2}$

Sixth was Leaf Area Index, using the formula:

$$
\mathrm{LD}=\mathrm{LD} / \mathrm{A}
$$

Where: LD is the leaf area above the soil surface with a certain area (e.g.: $1 \mathrm{~m}^{2}$ ), A is the land surface area. Seventh was dry weight $(\mathrm{g})$ in which all plant parts collected were dried in an oven at a constant temperature of $80^{\circ} \mathrm{C}$ for 48 hours. Dry weight was measured from sample plots measuring $1 \mathrm{~m} \mathrm{x} 1 \mathrm{~m}$, for example, dry weight per experimental plot was $100 \mathrm{~g} \times 1 \mathrm{~m}^{2}=100 \mathrm{~g} / \mathrm{plot}$ ).

The rate of decomposition was determined by the weight loss of the decomposed plant material. Determination of the sample was carried out by taking about $50 \mathrm{~g}$ of plant material and then placing it in a $20 \mathrm{~cm} \mathrm{x}$ $30 \mathrm{~cm}$ litter bag with fine holes made of nylon netting. The plant samples were placed between rows of oil palms aged 8,7 and 6 years. Observation of the rate of decomposition was carried out at 30 days and 60 days after treatment. The decomposition rate was then measured using the equation:

$$
\mathrm{R}=(\mathrm{W} 0-\mathrm{Wt}) / \mathrm{t}
$$

Where: R: decomposition rate (g/day), W0: initial biomass dry weight (g), Wt: dry weight of biomass after observation time $\mathrm{t}(\mathrm{g})$, $\mathrm{t}$ : observation time (days). This unit was then converted to $\mathrm{kg} / \mathrm{ha}$ to determine the total biomass weight of $N$. biserrata in oil palm plantations.

Analysis of the content of carbon organic, nitrogen, phosphorus and potassium contained in plant tissue was carried out using the wet digestion method according to technical guidelines provided by the Indonesian Soil Research Institute. Furthermore, the stored carbon content of the $N$. biserrata biomass was converted by calculating the carbon content as follow:

$\mathrm{C}$ content $=$ biomass $(\mathrm{kg} / \mathrm{ha}) \times$ carbon content $(\mathrm{C})$ in the plant

Calculation of soil carbon stock as follows:

$$
\text { C_Stok }=\mathrm{BV} \times \text { C_org } \times \mathrm{D} \times \mathrm{A}
$$

Where: C_stok: soil carbon stock (t ha-1), BV: soil bulk density (kg/m3), C_org: soil organic C content (\%), D: soil layer depth (m), A: land area (ha). 
Analyses of dry weight, plant organic contents and chemical properties of the soils were conducted in Integrated Agriculture Laboratory, Almuslim University, Aceh, Indonesia.

\section{RESULTS AND DISCUSSION}

\section{Growth percentage}

The results showed significant differences in the growth percentage of $N$. biserrata between all groups of planting years (Table 1). The older the oil palm age, the wider the canopy coverage. Thus, the areas under the canopy are highly shaded. This indicated the ability of $N$. biserrata to grow either in low or high shade conditions.

Table 1 presents the growth percentage of $N$. biserrata at various spacing and oil palm ages. At 4 to 8 WAP, the growth percentage was mainly below $50 \%$, especially at six years old oil palm plants at all spacing treatments. While at 7- and 8-years old oil palm plants, at $30 \times 30 \mathrm{~cm}$ spacing, the growth percentage was $>50 \%$. At $12 \mathrm{WAP}$, all spacing treatments showed $>50 \%$ growth percentage, but the highest growth percentage at all ages of oil palms was found at 30 $\mathrm{x} 30 \mathrm{~cm}$ spacing treatments, and the results were statistically significant at eight years old oil palm plants.

Table 1 also highlights $N$. biserrata potentials as a ground cover crop. It showed a rapid development rate in which within 12 WAP the growth percentage recorded at 73.99 - $81.16 \%$ at all oil palm stand ages observed. Furthermore, a significant difference was also observed at the spacing treatment of $30 \times 30 \mathrm{~cm}$ compared to $10 \times 10$ $\mathrm{cm}$ and $20 \times 20 \mathrm{~cm}$. In 2012 stands (8 years old), the spacing treatments of $10 \times 10 \mathrm{~cm}, 20 \times 20 \mathrm{~cm}$, and $30 \times 30$ $\mathrm{cm}$ produced an increase of $60.26 \%, 50.48 \%$ and $63.99 \%$, respectively. Increasing growth rate trends (58.8-69.9\%) were also observed in 7- and 6-years old oil palm stands in all spacing treatments where the highest percentage increase in growth was found in 6-year-old oil palm stands of $69.9 \%$. The significant difference in the growth percentage was confirmed using further statistical analysis, which resulted in $30 \times 30 \mathrm{~cm}$ spacing treatment producing the highest growth in all planting ages.

The rapid development of $N$. biserrata in the $30 \times 30$ $\mathrm{cm}$ spacing compared to other treatments at all planting years suggests the importance of spacing in ensuring optimal plant growth. It is known that spacing reduces the competition between plants on nutrition and sunlight; thus, the best result was exhibited at $30 \times 30 \mathrm{~cm}$ spacing. Growth percentage was obtained by calculating the ratio of the number of living plants and the population per planting area. Closer spacing resulted in competition in sunlight which is very important in photosynthesis and root development. Afterward, the roots will compete in water absorption. Hence, wider spacing lessens the competition and the plant will grow adequately.

\section{Cover percentage}

Statistical analysis on land cover percentage of $N$. biserrata at 8-, 7- and 6-years old oil palm stands were significantly different (Table 2). Spacing treatments showed significant differences instead of oil palm stands age. At 4 WAP, $N$. biserrata growth was not considered satisfying as the land cover percentage was in the range of 24.89$40.13 \%$ at all oil palm stands observed. At this initial stage, spacing of $30 \times 30 \mathrm{~cm}$ showed the highest land cover percentage at eight years old oil palm stand (40.13\%). At 8 WAP, a significant increase was observed at land cover percentage in which at a spacing of $10 \times 10 \mathrm{~cm}$ resulted in the highest increase of $51.97 \%, 51.39 \%$ and $50.85 \%$, respectively in 8-, 7- and 6-years old oil palm stands. Data collected at 12 WAP showed a maximum of $>75 \%$ land cover percentage at the spacing of $10 \times 10 \mathrm{~cm}$ and $20 \times 20$ $\mathrm{cm}$ in all oil palm stand ages observed. While the largest percentage of land cover was found in the $10 \times 10 \mathrm{~cm}$ spacing treatment at all ages of the observed oil palm stands.

Table 1. The growth percentage of Nephrolepis biserrata under various ages of oil palm stands at different spacing treatments at 4,8 , and $12 \mathrm{WAP}$

\begin{tabular}{lcccc}
\hline $\begin{array}{l}\text { Observation } \\
\text { time }\end{array}$ & $\begin{array}{c}\text { Spacing } \\
\text { treatments of } \\
N \text {. biserrata } \\
(\mathbf{c m})\end{array}$ & $\mathbf{4}$ & $\mathbf{4}$ & $\mathbf{6}$ \\
\cline { 3 - 5 } & $10 \times 10$ & $29.22^{\mathrm{bA}}$ & $28.88^{\mathrm{bA}}$ & $20.75^{\mathrm{aA}}$ \\
$4 \mathrm{WAP}$ & $20 \times 20$ & $37.42^{\mathrm{bB}}$ & $37.12^{\mathrm{bB}}$ & $24.89^{\mathrm{aA}}$ \\
& $30 \times 30$ & $49.61^{\mathrm{bC}}$ & $48.9^{\mathrm{bC}}$ & $33.9^{\mathrm{aB}}$ \\
& & & & \\
& $10 \times 10$ & $40.52^{\mathrm{aA}}$ & $40.12^{\mathrm{aA}}$ & $38.95^{\mathrm{aA}}$ \\
& $20 \times 20$ & $44.71^{\mathrm{bB}}$ & $43.16^{\mathrm{bA}}$ & $40.22^{\mathrm{aA}}$ \\
& $30 \times 30$ & $62.05^{\mathrm{bC}}$ & $59.33^{\mathrm{bB}}$ & $49.68^{\mathrm{aB}}$ \\
& & & & \\
$12 \mathrm{WAP}$ & $10 \times 10$ & $73.54^{\mathrm{bA}}$ & $70.14^{\mathrm{aA}}$ & $69.15^{\mathrm{aA}}$ \\
& $20 \times 20$ & $76.13^{\mathrm{bA}}$ & $71.75^{\mathrm{aA}}$ & $70.31^{\mathrm{aAB}}$ \\
& $30 \times 30$ & $81.16^{\mathrm{bB}}$ & $75.23^{\mathrm{aB}}$ & $73.99^{\mathrm{aB}}$ \\
\hline
\end{tabular}

Note: the numbers followed by the same letter notation in the same column and row are not significantly different on the 5\% LSD test. Lowercase notation is read horizontally, uppercase notation is read vertically. (WAP: weeks after planting. LSD: least significant difference)

Table 2. Percentage of land cover by Nephrolepis biserrata under different ages of oil palm at various spacing treatments at 4,8 , and 12 WAP

\begin{tabular}{lcccc}
\hline \multirow{2}{*}{$\begin{array}{l}\text { Observation } \\
\text { time }\end{array}$} & $\begin{array}{c}\text { Spacing } \\
\text { treatments of } \\
N \text { N biserrata } \\
(\mathbf{c m})\end{array}$ & \multicolumn{4}{c}{ Age of oil palm plants (Year) } \\
\cline { 3 - 5 } & $10 \times 10$ & $32.23^{\mathrm{bA}}$ & $30.12^{\mathrm{bA}}$ & $24.89^{\mathrm{aA}}$ \\
\hline $4 \mathrm{WAP}$ & $20 \times 20$ & $33.1^{\mathrm{bA}}$ & $33.01^{\mathrm{bA}}$ & $29.64^{\mathrm{aB}}$ \\
& $30 \times 30$ & $40.13^{\mathrm{bB}}$ & $38.56^{\mathrm{abB}}$ & $37.97^{\mathrm{aC}}$ \\
& & & & \\
& $10 \times 10$ & $66.31^{\mathrm{cC}}$ & $62.72^{\mathrm{bB}}$ & $50.65^{\mathrm{aB}}$ \\
& $20 \times 20$ & $59.92^{\mathrm{bB}}$ & $50.84^{\mathrm{aA}}$ & $48.72^{\mathrm{aAB}}$ \\
& $30 \times 30$ & $53.85^{\mathrm{cA}}$ & $49.99^{\mathrm{bA}}$ & $46.88^{\mathrm{aA}}$ \\
& & & & \\
$12 \mathrm{WAP}$ & $10 \times 10$ & $95.9^{\mathrm{bC}}$ & $92.9^{\mathrm{bC}}$ & $86.7^{\mathrm{aC}}$ \\
& $20 \times 20$ & $86.4^{\mathrm{bB}}$ & $84.1^{\mathrm{bB}}$ & $80.1^{\mathrm{aB}}$ \\
& $30 \times 30$ & $78.6^{\mathrm{cA}}$ & $75.4^{\mathrm{bA}}$ & $71.9^{\mathrm{aA}}$ \\
\hline
\end{tabular}

Note: the numbers followed by the same letter notation in the same column and row are not significantly different on the 5\% LSD test. Lowercase notation is read horizontally, uppercase notation is read vertically. (WAP: weeks after planting. LSD: least significant difference) 
The high land cover percentage of $N$. biserrata at $10 \mathrm{x}$ $10 \mathrm{~cm}$ spacing treatment was in line with a large population per unit area. Therefore, as a high number of $N$. biserrata was recorded, then $N$. biserrata population became the largest spacing. Land cover percentage of $N$. biserrata was recorded to be much higher than that of our previous finding on Asystasia intrusa, which were 74.67- 82.59\% at $10 \times 1 \mathrm{~cm}$ spacing and at 12 WAP (Satriawan et al. 2020).

Asbur et al. (2018) stated that land cover percentage indicates plant's speed in covering an area of cultivated land. Alonso-Ayuso et al. $(2014 ; 2018)$ proposed that cover crop regulates soil moisture content and inhibits other weeds growth, which would be detrimental for parent crops. Yet, the development of land cover crops is highly dependent on plant height/length, the number of branches and leaves and growth percentage (Suryana et al. 2019; Kaye et al. 2019).

\section{Plant height}

Due to its ease of observation, plant height has been used as a common indicator in studying plant growth. For this parameter, the observations in this study were conducted at 4-20 WAP. Data collected on various ages of oil palm stands indicated that spacing treatments of $N$. biserrata influenced plant height at 4, 8, 12, 16, and 20 WAP (Table 3). At 16 WAP, homogeny of plant growth was observed at 7- and 8-years old oil palm stands, while the spacing treatment with the bigest influence was $30 \times 30$ $\mathrm{cm}$.

Table 3. Height of Nephrolepis biserrata under various ages of oil palm stands at different spacing treatments. Data was collected at $0,4,8,12,16$, and $20 \mathrm{WAP}$

\begin{tabular}{|c|c|c|c|c|}
\hline \multirow{2}{*}{$\begin{array}{l}\text { Observation } \\
\text { time }\end{array}$} & \multirow{2}{*}{$\begin{array}{c}\text { Spacing } \\
\text { treatments of } \\
N . \text { biserrata } \\
\text { (cm) }\end{array}$} & \multicolumn{3}{|c|}{ Age of oil palm plants (year) } \\
\hline & & 8 & 7 & 6 \\
\hline \multirow{3}{*}{$0 \mathrm{WAP}$} & $10 \times 10$ & 12.5 & 12.4 & 12.1 \\
\hline & $20 \times 20$ & 12.6 & 12.5 & 12.4 \\
\hline & $30 \times 30$ & 12.8 & 12.4 & 12.4 \\
\hline \multirow[t]{3}{*}{$4 \mathrm{WAP}$} & $10 \times 10$ & $16.24^{\mathrm{aA}}$ & $15.15^{\mathrm{aA}}$ & $14.43^{\mathrm{aA}}$ \\
\hline & $20 \times 20$ & $17.3^{\mathrm{bA}}$ & $15.3^{\mathrm{abA}}$ & $14.97^{\mathrm{aA}}$ \\
\hline & $30 \times 30$ & $17.87^{\mathrm{bA}}$ & $15.71^{\mathrm{abA}}$ & $15.1^{\mathrm{aA}}$ \\
\hline \multirow[t]{3}{*}{$8 \mathrm{WAP}$} & $10 \times 10$ & $18.77^{\mathrm{bA}}$ & $17.24^{\mathrm{abA}}$ & $15.69^{\mathrm{aA}}$ \\
\hline & $20 \times 20$ & $19.16^{\mathrm{bA}}$ & $17.65^{\mathrm{abA}}$ & $16.33^{\mathrm{aA}}$ \\
\hline & $30 \times 30$ & $20.1^{\mathrm{bA}}$ & $17.91^{\mathrm{aA}}$ & $16.89^{\mathrm{aA}}$ \\
\hline \multirow[t]{3}{*}{12 WAP } & $10 \times 10$ & $20.15^{\mathrm{aA}}$ & $19.13^{\mathrm{aA}}$ & $18.22^{\mathrm{aA}}$ \\
\hline & $20 \times 20$ & $21.11^{\mathrm{bAB}}$ & $19.34^{\mathrm{abA}}$ & $18.97^{\mathrm{aA}}$ \\
\hline & $30 \times 30$ & $22.35^{\mathrm{bB}}$ & $19.78^{\mathrm{aA}}$ & $19.12^{\mathrm{aA}}$ \\
\hline \multirow[t]{3}{*}{16 WAP } & $10 \times 10$ & $23.13^{\mathrm{aA}}$ & $22.37^{\mathrm{aA}}$ & $21.43^{\mathrm{aA}}$ \\
\hline & $20 \times 20$ & $24.24^{\mathrm{aA}}$ & $22.89^{\mathrm{aA}}$ & $21.76^{\mathrm{aA}}$ \\
\hline & $30 \times 30$ & $24.88^{\mathrm{bA}}$ & $23.15^{\mathrm{abA}}$ & $22.01^{\mathrm{aA}}$ \\
\hline \multirow[t]{3}{*}{$20 \mathrm{WAP}$} & $10 \times 10$ & $26.82^{\mathrm{bA}}$ & $24.77^{\mathrm{aA}}$ & $23.44^{\mathrm{aA}}$ \\
\hline & $20 \times 20$ & $27.13^{\mathrm{bA}}$ & $25.23^{\mathrm{abA}}$ & $23.86^{\mathrm{aA}}$ \\
\hline & $30 \times 30$ & $28.34^{\mathrm{bA}}$ & $25.89^{\mathrm{abA}}$ & $24.1^{\mathrm{aA}}$ \\
\hline
\end{tabular}

Note: the numbers followed by the same letter notation in the same column and row are not significantly different on the 5\% LSD test. Lowercase notation is read horizontally, uppercase notation is read vertically. (WAP: weeks after planting. LSD: least significant difference)
May et al. (2020) stated that access to light, nutrients, and water compete among individual plants, and is crucial in plant development. Table 3 indicates that at wider spacing, $N$. biserrata showed tolerance to shade and showed no growth etiolation even at narrow spacing.

\section{Number of fronds}

The significant difference resulting from spacing treatments affected the growth of $N$. biserrata fronds in all ages of oil palm stands observed (Table 4). The highest number of fronds was obtained at the spacing treatment of $30 \times 30 \mathrm{~cm}$ compared to that of $10 \times 10 \mathrm{~cm}$ and $20 \times 20 \mathrm{~cm}$ at all oil palm stand's ages observed.

Based on Table 4, the number of fronds of $N$. biserrata per plant increased with increasing plant age. In WAP 424 , the increase in the number of fronds of $N$. biserrata per plant at all spacings and ages was almost the same, especially in oil palm stands of 6 and 7 years. Meanwhile, at the age of 8 oil palm stands showed little difference. Then due to the tight spacing, competition for sunlight, water, and nutrients cannot be avoided so that it inhibits plant growth, while at a rare spacing it can be avoided so that plants grow better.

Table 4. The number of Nephrolepis biserrata fronds under various ages of oil palm stands at different spacing treatments. Data collected at 4, 8, 12, 16, 20 and 24 WAP

\begin{tabular}{|c|c|c|c|c|}
\hline \multirow{2}{*}{$\begin{array}{l}\text { Observation } \\
\text { time }\end{array}$} & \multirow{2}{*}{$\begin{array}{c}\text { Spacing } \\
\text { treatments of } \\
\text { N. biserrata } \\
\text { (cm) }\end{array}$} & \multicolumn{3}{|c|}{ Age of oil palm (years) } \\
\hline & & 8 & 7 & 6 \\
\hline \multirow[t]{3}{*}{4 WAP } & $10 \times 10$ & $3.2^{\mathrm{bA}}$ & $2.3^{\mathrm{aA}}$ & $2.1^{\mathrm{aA}}$ \\
\hline & $20 \times 20$ & $3.5^{\mathrm{bA}}$ & $2.4^{\mathrm{aA}}$ & $2.3^{\mathrm{aA}}$ \\
\hline & $30 \times 30$ & $3.7^{\mathrm{bA}}$ & $2.7^{\mathrm{aA}}$ & $2.5^{\mathrm{aA}}$ \\
\hline \multirow[t]{3}{*}{8 WAP } & $10 \times 10$ & $4.5^{\mathrm{bA}}$ & $3.5^{\mathrm{aA}}$ & $3.4^{\mathrm{aA}}$ \\
\hline & $20 \times 20$ & $5.3^{\mathrm{bAB}}$ & $3.6^{\mathrm{aA}}$ & $3.3^{\mathrm{aA}}$ \\
\hline & $30 \times 30$ & $5.8^{\mathrm{bB}}$ & $3.9^{\mathrm{aA}}$ & $3.8^{\mathrm{aA}}$ \\
\hline \multirow[t]{3}{*}{$12 \mathrm{WAP}$} & $10 \times 10$ & $5.9^{\mathrm{aA}}$ & $5.1^{\mathrm{aA}}$ & $5.2^{\mathrm{aA}}$ \\
\hline & $20 \times 20$ & $6.8^{\mathrm{cAB}}$ & $4.8^{\mathrm{aA}}$ & $5.5^{\mathrm{bA}}$ \\
\hline & $30 \times 30$ & $7.1^{\mathrm{bB}}$ & $5.2^{\mathrm{aA}}$ & $5.9^{\mathrm{aA}}$ \\
\hline \multirow[t]{3}{*}{16 WAP } & $10 \times 10$ & $6.8^{\mathrm{aA}}$ & $6.2^{\mathrm{aA}}$ & $6^{\mathrm{aA}}$ \\
\hline & $20 \times 20$ & $7.8^{\mathrm{bB}}$ & $6.6^{\mathrm{aA}}$ & $6.2^{\mathrm{aA}}$ \\
\hline & $30 \times 30$ & $8.2^{\mathrm{bB}}$ & $6.5^{\mathrm{aA}}$ & $6.8^{\mathrm{aA}}$ \\
\hline \multirow[t]{3}{*}{$20 \mathrm{WAP}$} & $10 \times 10$ & $7.3^{\mathrm{aA}}$ & $7.1^{\mathrm{aA}}$ & $7.2^{\mathrm{aA}}$ \\
\hline & $20 \times 20$ & $8.4^{\mathrm{bB}}$ & $7.7^{\mathrm{aAB}}$ & $7.1^{\mathrm{aA}}$ \\
\hline & $30 \times 30$ & $9.7^{\mathrm{bC}}$ & $8.1^{\mathrm{aB}}$ & $7.7^{\mathrm{aA}}$ \\
\hline \multirow[t]{3}{*}{24 WAP } & $10 \times 10$ & $9.2^{\mathrm{aA}}$ & $9.1^{\mathrm{aA}}$ & $8.8^{\mathrm{aA}}$ \\
\hline & $20 \times 20$ & $10.3^{\mathrm{bAB}}$ & $9.9^{\mathrm{abAB}}$ & $8.9^{\mathrm{aAB}}$ \\
\hline & $30 \times 30$ & $11.6^{\mathrm{aB}}$ & $10.2^{\mathrm{aB}}$ & $10.1^{\mathrm{aB}}$ \\
\hline
\end{tabular}

Note: the numbers followed by the same letter notation in the same column and row are not significantly different on the 5\% LSD test. Lowercase notation is read horizontally, uppercase notation is read vertically. (WAP: weeks after planting. LSD: least significant difference) 


\section{Total leaf area and leaf area index}

Leaf Area Index quantifies the amount of a leaf area in a certain ecosystem and has such an important effect on processes such as photosynthesis, respiration, and interception of precipitation (Fang et al. 2019). Total Leaf Area of $N$. biserrata at all ages of oil palm stands was influenced by the spacing in which the $30 \times 30 \mathrm{~cm}$ spacing produced the highest Leaf Area, and Leaf Area Index. Figure 1 show that both parameters of the leaves of N.biserrata on oil palm plants aged eight years are larger and wider than those at the age of six and seven years. This result suggests that $N$. biserrata has the ability to grow in shaded conditions, and is not affected by light competition with the main crop (oil palm).

\section{Dry weight and decomposition rate}

Determination of dry weight indicates plant growth; thus, the determination was conducted on the whole plant. Therefore, the heavier the dry weight, the normal the plant growth. Plant dry weight analysis per treatment plot is presented in Table 5. A significant effect of spacing treatments on the dry weight of $N$. biserrata was found at 4,12 , and $20 \mathrm{WAP}$ in all oil palm stands age observed. The highest result was observed at $10 \times 10 \mathrm{~cm}$ spacing treatments which were significantly different compared to other spacing treatments (Table 5). The result might be in correspondence with fronds number and Leaf Area Index (Figures 1, 2, 3) in which the highest Leaf Area Index was also observed at $10 \times 10 \mathrm{~cm}$ spacing treatments in all oil palm stands. Gotoh et al. (2018) stated that plants with wider Leaf Area contain a higher chloroplast number, thus a higher photosynthesis rate as it has wider sunlight receiving surface area. Therefore, additional dry weight resulting from the photosynthesis activity in the form of carbohydrates was observed.

Table 5. A dry weight of Nephrolepis biserrata under various ages of oil palm stands at different spacing treatments. Data collected at 4,12 , and 20 WAP

\begin{tabular}{lcccc}
\hline \multirow{2}{*}{$\begin{array}{c}\text { Observation } \\
\text { time }\end{array}$} & $\begin{array}{c}\text { Spacing } \\
\text { treatments of } \\
N \text {. biserrata } \\
(\mathbf{c m})\end{array}$ & \multicolumn{4}{c}{ Age of oil palm (years) } \\
\cline { 3 - 5 } & $10 \times 10$ & $\mathbf{8}$ & 7 & $\mathbf{6}$ \\
\hline $4 \mathrm{WAP}$ & $20 \times 20$ & $139.4^{\mathrm{bC}}$ & $179.5^{\mathrm{bB}}$ & $132.7^{\mathrm{aB}}$ \\
& $30 \times 30$ & $119.8^{\mathrm{aA}}$ & $116.3^{\mathrm{ab}}$ & $109.8^{\mathrm{aAB}}$ \\
& & & & \\
& $10 \times 10$ & $705.2^{\mathrm{aA}}$ & $620.3^{\mathrm{bC}}$ & $488.7^{\mathrm{aB}}$ \\
$12 \mathrm{WAP}$ & $20 \times 20$ & $571.4^{\mathrm{bA}}$ & $494.2^{\mathrm{bB}}$ & $370.3^{\mathrm{aA}}$ \\
& $30 \times 30$ & $468.9^{\mathrm{bA}}$ & $380.8^{\mathrm{aA}}$ & $301.5^{\mathrm{aA}}$ \\
& & & & \\
$20 \mathrm{WAP}$ & $10 \times 10$ & $1054.20^{\mathrm{cC}}$ & $774.70^{\mathrm{bC}}$ & $653.70^{\mathrm{cB}}$ \\
& $20 \times 20$ & $838.60^{\mathrm{bB}}$ & $623.10^{\mathrm{aB}}$ & $580.80^{\mathrm{aAB}}$ \\
& $30 \times 30$ & $709.60^{\mathrm{bA}}$ & $520.30^{\mathrm{aA}}$ & $486.50^{\mathrm{aA}}$ \\
\hline
\end{tabular}

Note: the numbers followed by the same letter notation in the same column and row are not significantly different on the 5\% LSD test. Lowercase notation is read horizontally, uppercase notation is read vertically. (WAP: weeks after planting. LSD: least significant difference)

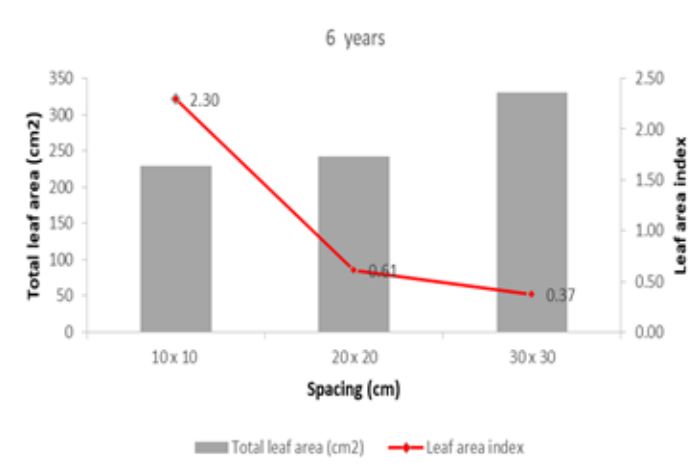

A

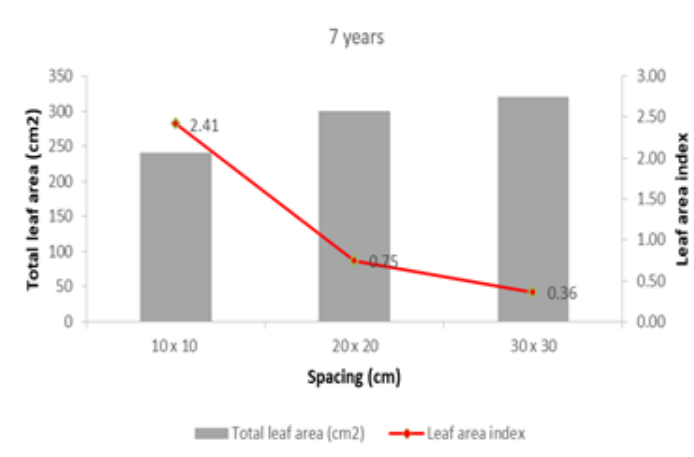

B

8 years

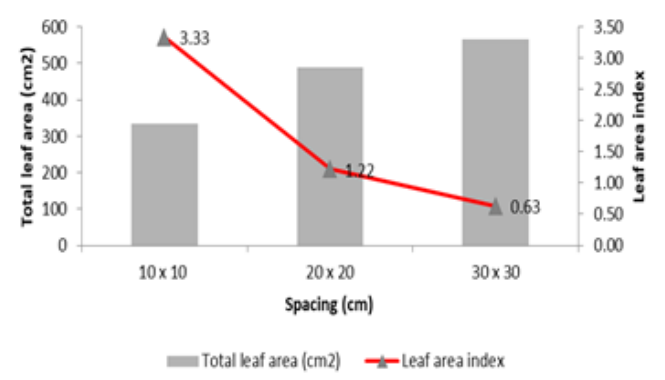

C

Figure 1. Total leaf area and leaf area index of Nephrolepis biserrata under various ages of oil palm stands at different spacing treatments. A. 6 years; B. 7 years; C. 8 years oil palm stands 
Conditions of oil palm stand at all observation ages influenced decomposition rates of $N$. biserrata. The highest and fastest decomposition rates were observed at six years old oil palm stands. Within 30 days, only $52.4 \%$ of total biomass was disintegrated at the rate of $1.75 \%$ per day. While at 60 days, a total of $73.2 \%$ of $N$. biserrata were decomposed. It can be concluded that $N$. biserrata is not quickly decomposed. Meanwhile, lower results were found at 8 and 7 years old of oil palm stands, which were $65.8 \%$ and $67.6 \%$ (Table 6). The results imply that plant age lowered the decomposition rate of plant litter below the canopy area. It is of importance as a slow decomposition rate enhances the sustainability of organic deposits which is important in sustaining the fertility of the soil. Our previous finding on other cover crop weeds of A. intrusa reported greater decomposition rates with $2.43 \%$ per day and $94.6 \%$ of total biomass (Satriawan et al. 2020).

Biomass weight loss of Melastoma malabathricum L. and oil palm fronds were reported to be greater than that of $N$. biserrata, which were 14 months of decomposition periods and loss of biomass were $83.1 \%$ and $87.6 \%$, respectively. Sulistiyanto et al. (2005) studied the decomposition of low pole forest and mixed swamp which found a longer decomposition time (18 months) than that of $N$. biserrata and A. gangetica. It is possible that fluctuations in environmental conditions such as light intensity and air temperature play an important role in affecting the decomposition rate of plant litter (Heviaa et al. 2003; Quideau et al. 2001).

\section{Plant tissue nutrient content and potential carbon stocks}

Statistical analysis of nutrient content of $N$. biserrata plant tissues indicates that organic carbon, $\mathrm{N}, \mathrm{P}$, and $\mathrm{K}$ contents were different in plant parts. Data indicated that the highest organic $\mathrm{C}$ content was found in the roots, while the highest contents of $\mathrm{N}, \mathrm{P}$, and $\mathrm{K}$ were found in the leaves. While the difference in oil palm stands age did not significantly affect nutrient contents in plant tissue (Table 7). It is interesting to note that the rate of decompositions is in correlation with macrofauna diversity and abundance (especially litter feeders) (Ashton-Butt et al. 2018). Since there is no data available on macrofauna composition in the study sites, further research will be needed.

The average of C-organic, $\mathrm{N}, \mathrm{P}$ and $\mathrm{K}$ contents of $N$. biserrata in the 8-year-old palm stand was $52.3 \%, 1.53 \%$, $0.22 \%$, and $1.67 \%$, respectively (Table 7 ). At 7 -year-old oil palm stand, the average of organic contents was $51.6 \% \mathrm{C}$ - organic, $1.40 \% \mathrm{~N}, 0.18 \% \mathrm{P}$, and $1.59 \% \mathrm{~K}$. Meanwhile, in a 6-year-old oil palm stand, the C-organic, N, P, and K levels were $49 \%, 1.23 \%, 0.20 \%$ and $1.44 \%$, respectively. Likewise, similar nutrient contents were reported in Thitonia diversifolia (Paitan) although at higher levels (Hartatik 2007). The results of this study are also in correspondence with the previous study on $N$. biserrata (Ariyanti et al. 2016), as well as Ageratum conyzoides, and A. gangetica (Asbur et al. 2018).

Nephrolepis biserrata plant tissue analysis that measured C-organic content and macronutrients (N, P, K) indicates its capacity to enrich soil through litter decomposition (Table 7). Ground cover crops are considered to be an ample substitute in generating nutrient supply and biomass to the soil (Landriscini et al. 2019). A previous study reported organic contents of A. gangetica are $33 \%$ C-organic, $3 \% \mathrm{~N}, 0.2 \% \mathrm{P}$, and $2 \% \mathrm{~K}$. Then, Paspalum conjugatum organic contents were $36 \%$ Corganic, $3 \% \mathrm{~N}, 0.3 \% \mathrm{P}, 2 \% \mathrm{~K}$, while A. conyzoides reported to be comprised of $37 \% \mathrm{C}$-organic, $3 \% \mathrm{~N}, 0.2 \% \mathrm{P}$, and $2 \% \mathrm{~K}$. The result of this study is in accordance to that of Ariyanti et al. (2016) which reported 51\% C-organic, $1 \% \mathrm{~N}, 0.2 \mathrm{P}$, and $2 \% \mathrm{~K}$ of $N$. biserrata in oil palm plantations in South Lampung. While another study in oil palm plantations in South Lampung reported $49 \%$ Corganic, $2 \% \mathrm{~N}, 0.3 \% \mathrm{P}$, and $5 \% \mathrm{~K}$ from A. gangetica (Asbur et al. 2016). This suggests that location is an important factor in organic matter and plant nutrient content.

The amount of carbon deposited in an ecosystem in biomass, soil carbon, or dead plants at a certain time is called carbon stock (Agus et al. 2011). The carbon stock potential of the dry weight of biomass is approximately 45$50 \%$. Hence, half of the total dry weight of the biomass is considered as plant the carbon stock (Hartoyo et al. 2019). In this study, a sample plot of $1 \mathrm{~m} \mathrm{x} 1 \mathrm{~m}$ was used to calculate carbon stock of $N$. biserrata plant biomass. Calculation shows that the amount of carbon stock stored on each part of it is as much as half of the total dry weight (Figure 2). A higher amount of biomass in a plant will elevate the carbon stock in an ecosystem. Biomass deposited in plant tissue can be as much as 0.6-0.9 tonnes $\mathrm{C} /$ ha/year. $N$. biserrata's biomass carbon stock was meager compared to oil palm fronds, M. malabathricum and Cycas sp. which reported to be as much as 9.4-12.2 ton/ha/year (Maswar 2009; Maswar et al. 2011), and tropical forest in Asia of 40-250 ton/ha (Lasco 2002).

Table 6. The decomposition rate of Nephrolepis biserrata under various ages of oil palm stands

\begin{tabular}{|c|c|c|c|c|c|c|c|}
\hline $\begin{array}{c}\text { Oil palm } \\
\text { plant age (years) }\end{array}$ & $\begin{array}{c}\text { Initial } \\
\text { weight }(g)\end{array}$ & $\begin{array}{l}\text { Weight after } \\
30 \text { days (g) }\end{array}$ & $\begin{array}{l}\text { Weight after } \\
60 \text { days (g) }\end{array}$ & $\begin{array}{c}\text { Decomposition } \\
\text { rate after } 30 \text { days } \\
(\% / \text { day })\end{array}$ & $\begin{array}{c}\text { Decomposition } \\
\text { rate after } 60 \text { days } \\
(\% / \text { day })\end{array}$ & $\begin{array}{c}\text { Biomass } \\
\text { decomposition } \\
\text { after } \mathbf{3 0} \text { days }(\%) \\
\end{array}$ & $\begin{array}{c}\text { Biomass } \\
\text { decomposition } \\
\text { after } 60 \text { days }(\%) \\
\end{array}$ \\
\hline 8 & 50 & $31.31^{\mathrm{c}}$ & $17.1^{\mathrm{a}}$ & $0.62^{\mathrm{a}}$ & $0.55^{\mathrm{b}}$ & $37.38^{\mathrm{a}}$ & $65.8^{\mathrm{b}}$ \\
\hline 7 & 50 & $27.5^{\mathrm{b}}$ & $16.2^{\mathrm{a}}$ & $0.75^{\mathrm{b}}$ & $0.56^{\mathrm{ab}}$ & $45^{\mathrm{b}}$ & $67.6^{\mathrm{b}}$ \\
\hline 6 & 50 & $23.8^{\mathrm{a}}$ & $13.4^{\mathrm{b}}$ & $0.87^{\mathrm{c}}$ & $0.61^{\mathrm{a}}$ & $52.4^{\mathrm{c}}$ & $73.2^{\mathrm{a}}$ \\
\hline
\end{tabular}


Table 7. Nutrient content percentages of various Nephrolepis biserrata plant tissues under various ages of oil palm stands

\begin{tabular}{|c|c|c|c|c|}
\hline \multirow{2}{*}{ Nutrient $(\%)$} & \multirow{2}{*}{ Plant organs } & \multicolumn{3}{|c|}{ Age of oil palm (years) } \\
\hline & & 8 & 7 & 6 \\
\hline \multirow[t]{3}{*}{ C-organic } & Roots & $48.23^{\mathrm{abA}}$ & $49.71^{\mathrm{bA}}$ & $46.55^{\mathrm{aA}}$ \\
\hline & Stems & $56.42^{\mathrm{bC}}$ & $54.99^{\mathrm{abB}}$ & $53.22^{\mathrm{aB}}$ \\
\hline & Leaves & $52.36^{\mathrm{cB}}$ & $50.02^{\mathrm{bA}}$ & $47.34^{\mathrm{aA}}$ \\
\hline \multirow[t]{3}{*}{$\mathrm{N}$} & Roots & $1.3^{\mathrm{aA}}$ & $1.25^{\mathrm{aA}}$ & $1.2^{\mathrm{aA}}$ \\
\hline & Stems & $1.1^{\mathrm{aA}}$ & $1.05^{\mathrm{aA}}$ & $0.9^{\mathrm{aA}}$ \\
\hline & Leaves & $2.2^{\mathrm{bB}}$ & $1.9^{\mathrm{abB}}$ & $1.6^{\mathrm{aA}}$ \\
\hline \multirow[t]{3}{*}{$\mathrm{P}$} & Roots & $0.2^{\mathrm{aAB}}$ & $0.2^{\mathrm{aB}}$ & $0.18^{\mathrm{aA}}$ \\
\hline & Stems & $0.15^{\mathrm{aA}}$ & $0.12^{\mathrm{aA}}$ & $0.13^{\mathrm{aA}}$ \\
\hline & Leaves & $0.3^{\mathrm{bB}}$ & $0.23^{\mathrm{aB}}$ & $0.3^{\mathrm{bB}}$ \\
\hline \multirow[t]{3}{*}{ K } & Roots & $1.1^{\mathrm{aA}}$ & $0.96^{\mathrm{aA}}$ & $1.01^{\mathrm{aA}}$ \\
\hline & Stems & $1.8^{\mathrm{aB}}$ & $1.6^{\mathrm{aB}}$ & $1.62^{\mathrm{aB}}$ \\
\hline & Leaves & $2.1^{\mathrm{bC}}$ & $2.2^{\mathrm{bC}}$ & $1.7^{\mathrm{aB}}$ \\
\hline
\end{tabular}

Note: the numbers followed by the same letter notation in the same column and row are not significantly different on the 5\% LSD test. Lowercase notation is read horizontally, uppercase notation is read vertically. (WAP: weeks after planting. LSD: least significant difference)

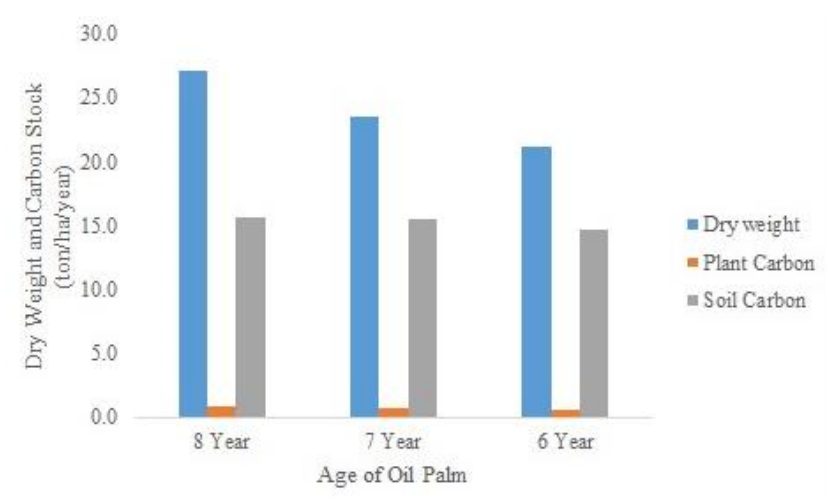

Figure 2. Biomass carbon stock of Nephrolepis biserrata under various ages of oil plant stands

\section{Soil carbon stocks}

Carbon and biomass are stored naturally in terrestrial ecosystems (Tarnocai et al. 2009). Carbon stored in the land significantly contributes to the reduction of greenhouse gas emissions and serves as an important indicator of soil's quality since it influences the physical, chemical, and biological properties of the soil (Bationo et al. 2006; Follet et al. 2009; Hou et al. 2012; Islam \& Weil 2000; Liu et al. 2011;). Our study found that $N$. biserrata under 8-year-old oil palm stands increased soil carbon stock by $127.72 \%, 99.43 \%$, and $68.36 \%$ at various depths observed (Figure 3). At a 7-year-old oil palm stand, the ability of $N$. biserrata in improving soil $\mathrm{C}$ organic content was $123.87 \%, 92.38 \%$, and $79.86 \%$ at various depths observed. While at 6-year-old oil palm stands, the increase of $\mathrm{C}$ organic stocks recorded at $111.25 \%, 74.95 \%$, and $58.07 \%$ at a depth of $0-10,10-20$ and $20-30 \mathrm{~cm}$, consecutively. Hence, it can be concluded that $N$. biserrata is able to increase carbon stock 1-2 times for every depth profile observed.

Factors, such as physical properties and the type of vegetation that grows on it, contribute to soil carbon contents (Ohkura et al. 2003; Shofiyati et al. 2010). Carbon which is produced during photosynthesis will be stored by plants and become the constituent materials of the tissue. When the whole plant, leaves, or twigs are dead, then it will be redelivered to the soil to be decomposed. The procedure will release $\mathrm{CO}_{2}$ gas into the air and some of it will be retained in the ground (Fujisaki et al. 2018).

The accumulation of soil carbon stock at 8-, 7- and 6years old oil palm stands at all soil profile depths was as much as 97.4, 84.6, and 76.4 tonnes/ha/year, consecutively. This result is in comparison with those recorded in tropical forests at comparable depths (5-180 tonnes/ha) (IPCC, 1997). However, a much lesser value (0.1 tonnes/ha) was reported in oil palm plantations in East Kalimantan (Sugirahayu and Rusdiana 2011). It is known that the physical and chemical properties of the soil are certainly impacted by the aggregation of carbon stock as well as groundwater upsurge. Plants will absorb the rest of total $\mathrm{CO}_{2}$ from the air and it will penetrate the soil again through plant litter, roots, and other organisms' decompositions (Hikmat 2005; Ruddiman 2007).

In conclusion, $N$. biserrata is an ideal ground cover crop due to its rapid growth in covering the landscape (12 WAP), fast decomposition (30-60 days), tolerance in shaded conditions $(81.16 \%$ growth percentage, $95.9 \%$ area covering in all ages oil palm stands observed), high nutrient contents i.e. N (1.23-1.53\%), P (0.18-0.22\%), and K (1.4$1.67 \%)$, potential biomass ( 0.9 ton $\mathrm{C} / \mathrm{ha} /$ year), soil carbon stocks (76.4 - 97.4 tonnes /ha/year), and able to increase soil carbon stock up to $127.72 \%$. Thus, certain weeds such as $N$. biserrata can be used as part of an environmentally friendly oil palm cultivation technology, with the advantage of being able to contribute soil carbon and nutrients so that the need for fertilizer for oil palm can be reduced. Moreover, the recommendation of the most optimum spacing treatments of $N$. biserrata from this study is also need to be applied in order to get the intended result when the method wants to be applied widely.

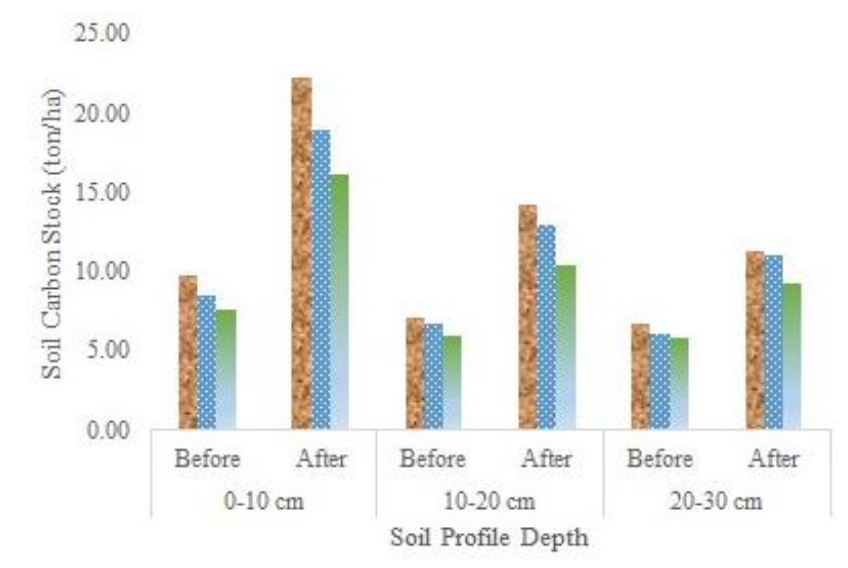

Figure 3. Soil carbon stock (ton/ha) at various soil profile depths $(0-30 \mathrm{~cm})$ under various ages of oil palm stands 


\section{ACKNOWLEDGEMENTS}

The authors express the appreciation and gratitude to the Directorate of Research and Community Service Deputy for Research and Technology Strengthening Ministry of Education, Cultural, Research and Technology with LLDIKTI Region XIII Number 02 / LL13 / AKA/ LT / 2021.

\section{REFERENCES}

Adeleye MA, Akinsoji A, Adeonipekun PA. 2017. A Survey of Vascular Epiphytes of Oil Palms (Elaeisguineensis Jacq.) in Lekki Conservation Centre, Lagos, Nigeria. Federal University Wukari Taraba State, Nigeria.

Agus F, Hairiah K, Mulyani A. 2011. Pengukuran Cadangan Karbon Tanah Gambut. Petunjuk Praktis. World Agroforestry Centre-ICRAF, SEA Regional Office dan Balai Besar Penelitian dan Pengembangan Sumberdaya Lahan Pertanian (BBSDLP), Bogor, Indonesia. [Indonesian]

Ali NBM, Karim MFA, Saharizan N, Adnan NS, Mazri NH, Fikri NA, Amaludin NA, Zakaria R. 2021. Weeds diversity in oil palm plantation at Segamat, Johor. IOP Conf Ser: Earth Environ Sci 756: 012034. DOI: 10.1088/1755-1315/756/1/012034.

Alonso-Ayuso M, Gabriel JL, Quemada M. 2014. The kill date as a management tool for cover cropping success. PLoS One 9 (10): e109587. DOI: 10.1371/journal.pone.0109587.

Alonso-Ayuso M, Gabriel JL, García-González I, Del Montea JP, Quemada M. 2018. Weeddensity and diversity in a long-term cover cropexperiment background. Crop Protec 112: 103-111. DOI: 10.1016/j.cropro.2018.04.012.

Ariyanti M, Yahya S, Murtilaksono K, Suwarto, Siregar HH. 2016. The influence of cover crop Nephrolepis biserrata and ridge terrace against run off and the growth of oil palm (Elaeis guineensis Jacq.). Jurnal Kultivasi 15 (2): 121-127. DOI: 10.24198/kltv.v15i2.11889. [Indonesian]

Asbur Y, Yahya S, Murtilaksono K, Sudradjat, Sutarta ES. 2016. The roles of Asystasia gangetica (L.) T. Anderson and ridge terrace in reducing soil erosion and nutrient losses in oil palm plantation in South Lampung, Indonesia. J Trop Crop Sci 3 (2): 49-55. DOI: 10.29244/jtcs.3.2.49-55.

Asbur Y, Rambe RDH, Purwaningrum Y, Kusbiantoro D. 2018. Potensi beberapa gulma sebagai tanaman penutup tanah di perkebunan kelapa sawit menghasilkan. J Penelitian Kelapa Sawit 26 (3): 113-128. DOI: 10.22302/iopri.jur.jpks.v26i3.69. [Indonesian]

Ashton-Butt A, Aryawan Anak AK, Hood Amelia SC, Naim M, Purnomo D, Suhardi, Wahyuningsih R. 2018. Understory vegetation in oil palm plantations benefits soil biodiversity and decomposition rates. Front For Global Change 1: 10. DOI: 10.3389/ffgc.2018.00010.

Austin KG, Mosnier A, Pirker J, McCallum I, Fritz F, Kashibatla PS. 2017. Shifting patterns of oil palm driven deforestation in Indonesia and implications for zero-deforestation commitments. Land Use Policy 69: 41-48.

Badan Koordinasi Penanaman Modal (BKPM). 2017. Regional superior commodities. [Indonesian]

Bationo A, Kihara J, Vanlauwe B, Waswa B, Kimetu J. 2006. Soil organic carbon dynamic, functions, and management in West African agroecosystems. Agric Syst 94 (1): 13-25. DOI 10.1016/j.agsy.2005.08.011.

Bonhommeau S, Dubroca L, Le Pape O, Barde J, Kaplan, DM, Chassot E. 2013. Eating up the world's food web and the human trophic level. Proc Natl Acad Sci USA. 110: 20617-20620. DOI: 10.1073/pnas.1305827110.

Directorate General of Estate Crops. 2017. Indonesian plantation statistics 2015-2017: the oil palm. Direktorat Jenderal Perkebunan, Kementerian Pertanian. [Indonesian]

Evrizal R. 2003. Pembibitan dan penanaman Arachis pintoi sebagai penutup tanah di kebun. J Agrotropika 8: 1-5. [Indonesian]

Fang H, Baret F, Plummer S, Schaepman-Strub G. 2019. An overview of global Leaf Area Index (LAI): methods, products, validation, and applications. Rev Geophys 57 (3): 739-99. DOI: 10.1029/2018RG000608.

Fujisaki K, Chevallier T, Chapuis-Lardy L, Albrecht A, Razafimbelo T, Masse D, NdourYB, Chotte JL. 2018. Soil carbon stock changes in tropical croplands are mainly driven by carbon inputs: a synthesis. Agric Ecosyst Environ 259: 147-58. DOI: 10.1016/j.agee.2017.12.008.

Food Agriculture Organisation (FAO). 2017. United Nations, Statistics Division.

Godfray HCJ, Crute IR, Haddad L, Lawrence D, Muir JF, Nisbett N. 2010. The future of the global food system. Philos. Trans R Soc Lond B Biol Sci 365: 2769-2777. DOI: 10.1098/rstb.2010.0180.

Gotoh E, Noriyuki S, Wataru Y, Kazuhiro I, Ryota K, Masako F, Takeshi H, Bungo S, Masamitsu W. 2018. Chloroplast accumulation response enhances leaf photosynthesis and plant biomass production. Plant Physiol 178 (3): 1358-1369. DOI: 10.1104/pp.18.00484.

Hartatik W. 2007. Thitonia diversifolia sumber pupuk hijau. Warta Penelitian dan Pengembangan Pertanian 29 (5): 3-5. [Indonesian]

Hartoyo APP, Prasetyo LB, Siregar IZ, Supriyanto, Theilade I, Siregar UJ. 2019. Carbon stock assessment using forest canopy density mapper in agroforestry land in Berau, East Kalimantan, Indonesia. Biodiversitas 20 (9): 2661-2676. DOI: 10.13057/biodiv/d200931.

Heviaa GG, DE Buschiazzoa, EN Heppera. 2003. Organic matter in size fractions of soils of the semiarid Argentina. Effects of climate, soil texture and management. Geoderma 116: 265-277. DOI: 10.1016/S0016-7061(03)00104-6.

Hikmat A. 2005. Biomass estimation, carbon storage and energy content of three virgin jung reserves in Peninsular Malaysia. Media Konservasi. 10 (2): $1-8$. DOI: $10.29244 /$ medkon. $10.2 . \% 25$ p. [Indonesian]

Hou R, Li ZOY, Tyler DD, Li F, Wilson GF. 2012. Effect of tillage and residue management on soil organic carbon and total nitrogen in the North China Plain. Soil Sci Soc Am J 76 (1): 1-11. DOI: 10.2136/sssaj2011.0107.

Islam KR, Weil RR. 2000. Soil quality indicator properties in MidAtlantic soils as influenced by conservation management. J Soil Water Conserv 55 (1): 69-78.

Kanders MJ, BBarendo C, Fritz C, Watson C, Wichern F. 2017. Catch crops store more nitrogen below-ground when considering rhizodeposit. Plant Soil 417 (1): 287-299. DOI: 10.1007/s11104-0173259-0.

Kaye J, Finney D, White C, Bradley B, Schipanski M, Alonso-Ayuso M. 2019. Managing nitrogen through cover crop species selection in the U.S. mid-Atlantic. PLoS ONE 14 (4): e0215448. DOI: 10.1371/journal.pone.0215448.

Kruidhof HM, Bastian L, Kropff MJ. 2009. Cover crop residue management for optimizing weed control. Plant Soil 318: 169-184. DOI 10.1007/s11104-008-9827-6.

Landriscini MR, Galantini JA, Duval ME, Capurro JE. 2019. Nitrogen balance in a plant-soil system under different cover crop-soybean cropping in Argentina. Appl Soil Ecol 133: 124 -131. DOI: 10.1016/j.apsoil.2018.10.005.

Larkin RP. 2015. Soil health paradigms and implications for disease management. Ann Rev Phytopathol 53: 199-221. DOI: 10.1146/annurev-phyto-080614-120357.

Lasco RD. 2002. Forest carbon budgets in Southeast Asia following harvesting and land cover change. In: Impacts of land use Change on the Terrestrial Carbon Cycle in the Asian Pacific Region. Sci China 45: 76-86.

Laurance WF, Sayer J, Cassman KG. 2014. Agricultural expansion and its impacts on tropical nature. Trends Ecol Evol 29, 107-116. DOI: 10.1016/j.tree.2013.12.001.

Liu Z, Shao M, Wang Y. 2011. Effect of environmental factors on regional soil organic carbon stock across the losses plateau region, China. Agric Ecosyst Environ 142 (3-4): 184-194. DOI: 10.1016/j.agee.2011.05.002.

Liu X, Hannula SE, Li X, Hundscheid MPJ, Gunnewiek PJAK, Clocchiatti S, Ding W, de Boer W. 2021. Decomposing cover crops modify root-associated microbiome composition and disease tolerance of cash crop seedlings. Soil Biol Biochem 160: 108343 DOI: $10.1016 /$ j.soilbio.2021.108343.

Maswar. 2009. Kecepatan dekomposisi biomassa dan akumulasi karbon pada konversi lahan gambut menjadi perkebunan kelapa sawit. Prosiding dan Lokakarya Nasional Inovasi Sumberdaya Lahan. Buku II: Teknologi Konservasi, Pemupukan, dan Biologi Tanah. Balai 
Besar Penelitian dan Pengembangan Sumberdaya Lahan Pertanian. Badan Penelitian dan Pengembangan Pertanian, Kementerian Pertanian. [Indonesian]

Maswar, Haridjaja O, Sabiham S, van Noordwijk M. 2011. Cadangan, kehilangan, dan akumulasi karbon pada perkebunan kelapa sawit di lahan gambut tropika. Jurnal Solum 8 (1): 1-10. DOI: 10.25077/js.8.1.1-10.2011. [Indonesian]

May WE, Aldous L, Guy P. Lafond. 2020. Feasibility of a wider row spacing and recommended nitrogen in no-till wheat. Agron J 112 (5): 4076-91. DOI: 10.1002/agj2.20316.

Norlindawati AP, Haryani H, Sabariah B, Noor MI, Samijah A, Mohd Supie J, Edham ZW. 2019. Chemical composition of weeds as potential forage in integrated farming. Malay J Vet Res 10 (2): 19-24.

Ohkura T, Yokoi Y, Imai H. 2003. Variations in soil organic carbon in Japanese arable lands. In: Smith CAS (eds) Soil organic carbon and agriculture: developing indicators for policy analyses. Proceedings of an OECD expert meeting, Ottawa Canada.

Purba A, Rahutomo S. 2000. Introduksi kacangan penutup tanah alternatif Arachis pintoi pada areal kelapa sawit belum menghasilkan. Warta Pusat Penelitian Kelapa Sawit 8: 63-67. [Indonesian]

Putra ETS, Simatupang AF, Supriyatna, Waluyo S, Indradewa D.2012. The growth of one year-old oil palms intercropped with soybean and groundnut. J Agric Sci 4 (5): 169-180. DOI: 10.5539/jas.v4n5p169.

Quideau SA, Chadwick, Benesi A, Graham RC, Anderson MA. 2001. A direct link between forest vegetation type and soil organic matter composition. Geoderma 104: 41-60. DOI: 10.1016/S00167061(01)00055-6.

Robert M. 2001. Soil Carbon Sequestration for Improved Land Management. Food and Agriculture Organization (FAO) of the United Nations. Rome.

Rodríguez AC, D’Aronco S, Schindler K, Wegner JD. 2021. Mapping oil palm density at country scale: An active learning approach. Remote Sens Environ 261 (2021): 112479. DOI: 10.1016/j.rse.2021.112479.

Samedani B, Juraimi AS, Anwar MP, Rafii MY, Sheikh Awadz SH, Anuar AR. 2013. Competitive interaction of Axonopus compressus and Asystasia gangetica under contrasting sunlight intensity. Sci World J. DOI: 10.1155/2013/308646.

Satriawan H, Fuady Z, Ernawita. 2020. The potential of Asystasia intrusa weed as a cover crop in oil palm plantations. Biodiversitas 21 (12): 5710-5717. DOI: 10.13057/biodiv/d211230.
Satriawan H, Fuady Z. 2019. Analysis of weed vegetation in immature and mature oil palm plantations Biodiversitas 20 (11): 3292-3298. DOI: $10.13057 /$ biodiv/d201123.

Satriawan H, Fuady Z. 2014. Teknologi Konservasi Tanah dan Air. Deepublish, Yogyakarta, Indonesia. [Indonesian]

Shofiyati R, Las I, Agus F. 2010. Indonesian soil data base and predicted stock of soil carbon. Proceeding of International Workshop on Evaluation and Sustainable Management of Soil Carbon Sequestration in Asian Countries. Bogor, Indonesia 28-29 September 2010. [Indonesian]

Sugirahayu L, Rusdiana O. 2011. Perbandingan simpanan karbon pada beberapa penutupan lahan di Kabupaten Paser, Kalimantan Timur berdasarkan sifat fisik dan sifat kimia tanahnya. Jurnal Silvikultur Tropika 2 (3): 149-155. [Indonesian]

Sulistiyanto Y, Rieley JO, Limin SH. 2005. Laju dekomposisi dan pelepasan hara dari serasah dari dua sub-tipe hutan rawa gambut di Kalimantan Tengah. Jurnal Manajemen Hutan Tropika 11 (2): 1-14. [Indonesian]

Suryana, Chozin MA, Guntoro D. 2019. Species identification for cover crop on mature oil palm plantation. J Agron Indonesia 47 (3): 305311. DOI: DOI: $10.24831 /$ jai.v47i3.26980.

Statista. 2020. Volume of total oil palm exports from Indonesia from 2011 to 2020 . https://www.statista.com/statistics/1095541/indonesia-palmoil-export-volume/

Tarnocai C, Canadell JG, Schuur EAG, Kuhry P, Mazhitova G, Zimov S. 2009. Soil organic carbon pools in the northern circum polar permafrost region. Global Biogeochem Cycles 23 (2): 1-11. DOI: 10.1029/2008GB003327.

Tilman D, Fargione J, Wolff B, D'Antonio C, Dobson A, Howarth R. 2001. Forecasting agriculturally driven global environmental change. Science 292 (5515): 281-284. DOI: 10.1126/science.1057544.

Wen L, Lee-Marzano S, Ortiz-Ribbing LM, Gruver J, Hartman GL, Eastburn DM. 2017. Suppression of soilborne diseases of soybean with cover crops. Plant Dis 101 (11): 1918-28. DOI: 10.1094/PDIS07-16-1067-RE.

Wilcove DS, Giam X, Edwards DP, Fisher B, Koh LP. 2013. Navjot's nightmare revisited: logging, agriculture, and biodiversity in Southeast Asia. Trends Ecol Evol 28 (9): 531-540. DOI: 10.1016/j.tree.2013.04.005. 